\title{
RECLAIMING SUBJECTIVITY IN SURVEY RESEARCH: INSIGHTS FROM A PILOT STUDY IN A UNIVERSITY DEPARTMENT
}

\author{
Michael Joseph, Hlulani Mabasa, Thembinkosi Mabila, Simon Mothoa and Esther Ramani \\ University of the North
}

An existing document at the University of the North on the language profiles of its employees classifies them into 'English' and/or Northern Sotho' speakers. The mismatch between this simplistic picture and the multilingual richness that we know is there motivated the authors of this article to embark on a large-scale quantitative survey of multilingualism at UNIN. However, the collection of data from the entire university turned out to be tedious and unwieldy, and led to an overproliferation of data and its underanalysis.. This spurred us to do a small-scale pilot survey of the English Studies department, in which we used individual and collective prediction as a tool to drive the research process. In this article we describe and theorise this experience and affirm the value of subjectivity in quantitative survey research. We explore the cognitive and social value of subjectivity and discuss its role in building a communal approach to research projects. We further relate our insights from the pilot study to recommendations about research methodology made in two recent South African educational documents, LANGTAG (1996) and Getting Learning Right (1999) and thus hope to contribute to debates on research methodology.

'n Bestaande dokument oor die taalprofiele van werknemers van die Universiteit van die Noorde klassifiseer werknemers as 'Engels- en/of Noord-Sotho-sprekend'. Die wanvoorstellings van hierdie eenvoudige beskrywing en die multitalige rykdom wat ons wéét wel bestaan, het die skrywers van hierdie artikel gemotiveer om 'n grootskaalse kwantitatiewe ondersoek na multitaligheid aan die UNIN te doen. Dit het egter geblyk dat die versamelde data van die hele universiteit langdradig en onhanteerbaar is, wat gelei het tot ' $n$ oorprofilering van data en verdere analises. Dit het ons aangespoor om 'n loodsondersoek op klein skaal van die Departement van Engelse Studies te doen, waarin ons individuele en kollektiewe prognose gebruik het as dryfveer vir die navorsingsproses. In hierdie artikel beskryf en teoretiseer ons hierdie bevinding, en bevestig ons die waarde van subjektiwiteit in navorsing oor kwantitatiewe ondersoeke. Ons ondersoek die kognitiewe en sosiale waarde van subjektiwiteit, en bespreek die rol daarvan in die uitbou van 'n gemeenskaplike benadering tot navorsingsprojekte. Ons insigte uit die loodsondersoek word voorts gekoppel aan aanbevelings oor navorsingsmetodologie in twee onlangse Suid-Afrikaanse opvoedkundige dokumente, LANGTAG (1996) en Getting Learning Right (1999), en ons hoop dus om ' $n$ sinvolle bydrae te lewer tot navorsingsmetodologie.

\section{INTRODUCTION}

In this article we seek to describe and theorise our experience of doing a pilot study for a large-scale quantitative survey of multilingualism at the University of the North (UNIN). Our aim is to show how we used prediction as a tool in this survey research to tap into our beliefs 
as a basis for driving the research. It is the norm in large-scale empirical research to follow the linear process of first collecting all the data and then analysing it to arrive at some patterns, trends and generalisations. We would like to demonstrate how we moved away from this model of doing survey research. The new mode of research that we discovered enabled us to use our own subjective beliefs to shape the research process.

The context for the survey research is the Northern Sotho Language Project (NSLP) at the University of the North (UNIN). The authors of this article are five of the seven members of the research team of this project. The other two members are teacher-researchers, Maite Mmako and Mafori Makgahlela, who are being trained to teach Northern Sotho to a group of adult non-Northern Sotho academic and administrative staff at UNIN. The project is conceived of primarily as a research project, is internally funded by UNIN and registered in the department of English Studies with close collaboration from the departments of Northern Sotho and Adult Education. More details about the project are provided in Appendix B.

The project aims to do the following:

i) investigate the teaching and learning of Northern Sotho in a naturalistic/psycholinguistic paradigm (Prabhu 1987, Joseph \& Ramani 1997, Joseph \& Ramani 1998) and more generally to contribute to research on second/subsequent language acquisition and to debates on the role of implicit/explicit grammar teaching in formal language learning contexts.

ii) promote multilingualism by enabling non-Northern Sotho speakers to learn Northern Sotho.

iii) transfer resources (materials, methodology, research procedures and processes of professionalisation) from English, the world's most highly-resourced language, to African languages

iv) create the conditions for high-quality community research, in which trainers/supervisors, teachers, research assistants and learners can collectively own and benefit from the research.

This article will focus on the last aim. We would like to demonstrate how researchers and supervisors could do research in such a way that the subjectivities of all team members are tapped, valued and used to drive the research process. We will be describing the exploratory efforts of our research team to use our own beliefs and predictions as a tool to do a sociolinguistic survey of UNIN staff.

We thought it important to carry out a sociolinguistic survey to get an accurate description of the multilingual competence of UNIN employees. Our analysis of existing UNIN documents revealed an incomplete and inadequate classification of staff into two categories: 'Northern Sotho' speakers and 'English' speakers. Aware that the multilingual situation at UNIN is much more complex, we decided to carry out our own survey, which among other things, would reveal who needed to learn Northern Sotho. This data was to feed into the needs analysis of potential learners for the Northern Sotho Language Project. 


\section{MAPPING THE LOCAL ONTO THE NATIONAL}

Our aim to do a multilingual survey of UNIN staff and our method are related to two major documents that have recently appeared in South Africa. These are the Language Plan Task Group report or LANGTAG (1996) which serves to guide multilingual policy in the country and 'Getting Learning Right'(or GLR as we will refer to it hereafter) edited by Taylor and Vinjevold (1999). The latter is the first major recent report of case studies of educational practice in South Africa. Since our article engages mainly with these two documents we will not do an extensive literature survey.

The first of these documents, the LANGTAG report calls for demographic studies and sociolinguistic surveys to establish the language profiles of different communities and groupings. It provided us with the initial impetus to carry out our own survey.

GLR is a document that we began to relate our project to at a much later stage of our own survey. Our main reason for connecting up with this document is the argument advanced in it for doing "relatively large-scale studies leading to generalisable results" (Vinjevold \& Taylor 1999: 104). Also by linking our work with the debates on methodology reported in GLR (Muller in Vinjevold \& Taylor 1999: 37-64), we hope to locate our own position on the national methodological map that we see GLR as providing. The value of the GLR document is that it goes beyond a report on classroom contexts and practices towards opening up a debate on research methods. We hope to thus extend the debate started by GLR. More observations on these key documents follow.

\section{THE LANGTAG REPORT}

The LANGTAG report, we believe, correctly argues for a massive campaign to promote multilingual awareness against the growing threat of 'the monolingual trend' caused by the popularity of English. This trend towards monolingualism is confirmed more recently in the GLR report. However, the numerous surveys of a perspectival nature (people's opinions and preferences) that have been carried out since the emergence of LANGTAG, are based on a one-sided definition of 'additive multilingualism'. We have more thoroughly examined this definition in another article (Granville et al 1998). We pointed out there that the term 'additive multilingualism' is usually applied to the majority section of the population, namely, African speaking people. The concern is for how African speakers can gain a second language (usually English) without losing their home language.

Such a definition ignores those sections (constituting about $25 \%$ of the South African population) that speak a dominant language (English or Afrikaans). In our view, these nonAfrican language speakers too need to become multilingual, especially in an African language. In addition, the possible enrichment of African first language literacy through African second language pedagogy must not be underestimated.

\section{GETTING LEARNING RIGHT (GLR)}

So while the LANGTAG has espoused the need for demographic studies, it has tended to eclipse the need of the non-African language speaking population to learn an African language. Besides this, LANGTAG has tended to encourage investigations into the issue of 
language choice, based on interviewing people for their preferences. This is the kind of investigation referred to in the GLR as the collection of 'perspectival data' (Vinjevold \& Taylor 1999:104). According to GLR, there has been 'a heavy reliance on self-report (perspectival) data' and a failure to examine actual language learning conditions. They deem this to be a major methodological shortcoming.

However, the authors of GLR point out that there have also been major methodological gains not only due to the shift towards a greater use of classroom observations, but also in 'the sophistication and rigour of these methods'. They point out to 'an increase in the number of projects using quantitative methods despite exhibiting "methodological flaws". GLR represents a serious effort to go beyond 'perspectival data', case studies, and the debilitating effects of an extreme form of postmodernist thinking that espouses relativism. It calls for a 'search for generalisations' which according to the GLR 'should feature at the top of the list of future research priorities'. All these views appear in the article by Vinjevold and Taylor (1999:65-104) cited above.

We find ourselves in broad agreement with GLR and see our attempt to do a large-scale quantitative survey as being in tune with its recommendations.

\section{THE EXISTING UNIN DOCUMENT}

Responding to both the LANGTAG document (which calls for demographic studies and multilingual surveys) and GLR (which calls for large-scale research as the basis for generalisations), we decided to do a sociolinguistic survey of UNIN. We began first by searching for any existing documents that might throw light on UNIN employees' linguistic profiles. After a long and tiresome process, we managed to get the document reproduced below (Table 1). It is in exactly the same format as the original UNIN document obtained from the Personnel department at UNIN. The document does not give language backgrounds for non-South African academic contract staff. Also no explanation was given for why some figures do not add up to the expected totals. 
Table 1: UNIN empoyees' profile (official document)

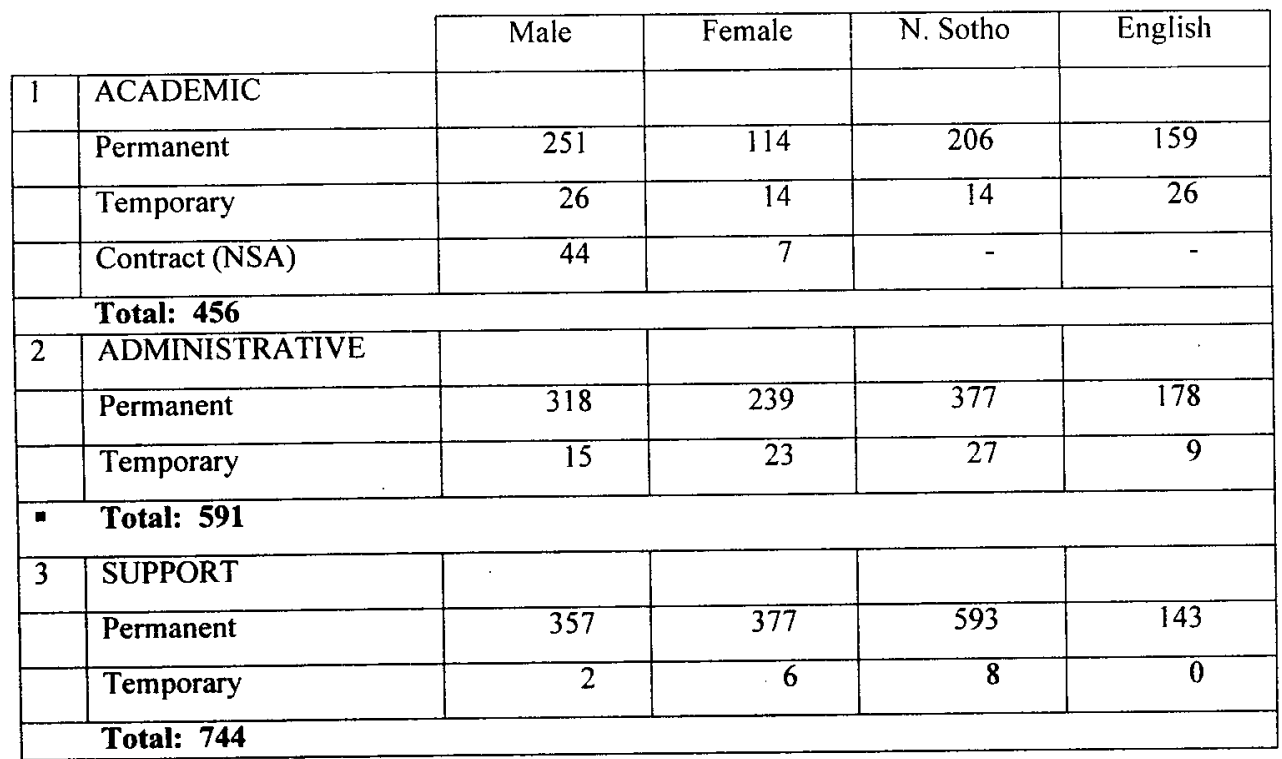

According to this document, the University classifies its employees into three categories: academic staff, administrative staff and support staff (cleaners, messengers, etc). It is interesting to note that there are more males in the academic and administrative categories than females, while in the support staff category, there are more females. There also seem to be no contract staff employed in the administrative and support categories.

But what is most striking in this document is the classification of employees into Northern Sotho and English-speaking staff. Every employee in the University who is able to speak Northern Sotho is classified as a Northern Sotho speaker even if that person's mother tongue or home language is not Northern Sotho.

Any employee in the University who is not able to speak Northern Sotho is classified as 'English'. In other words a Xitsonga or Afrikaans-speaking person who cannot speak Northern Sotho is classified as 'English'. We realised that the document distorts the University employees' language profiles. It homogenises the non-Northern Sotho population and hides the sociolinguistic diversity that we know is there.

\section{OUR SURVEY QUESTIONNAIRE}

To correct the distorted sociolinguistic profile of the University, the research team decided to conduct its own survey. The instrument of data collection was a questionnaire (Appendix A). Section $\mathrm{A}$ of the questionnaire sought demographic data, including gender, nationality. languages known, etc. whereas Section B was aimed at finding out if non-Northern Sotho speakers would want to learn Northern Sotho and why. Questions on whether potential learners had tried to learn it before and what methods of learning they had experienced would 
serve as a more refined needs analysis to drive the teaching side of the Northern Sotho Language Project.

\section{The Pilot Survey}

However, soon after we started the university-wide survey, we felt inundated by the data. We realised that the massive collection of data without continuous theorising had resulted in our being overwhelmed by the process. To avoid the dangers of the over-production and underanalysis of data, we decided to do a pilot study. We chose to pilot our questionnaire in the Department of English Studies, where most of the research team members are located. While we were aware that the English Studies department may not be representative of the whole university, and its staff may be more sensitive to language issues, we felt our very familiarity with this department would enable us tap our subjectivities.

This pilot study would enable us to revise our questionnaire and to establish the sociolinguistic profile of an individual department. In addition, we would find out if staff who did not know Northern Sotho would be motivated to learn it.

\section{Our Beliefs}

However, in discussing our research plan, we realised that each of us had certain beliefs about who among the English department staff would want to learn Northern Sotho. We decided to make individual predictions about which 'categories' of staff would be most motivated to learn Northern Sotho. We felt such predictions would make our data collection more interesting and it would be exciting to see whether our predictions would match our findings.

Through collective discussion we evolved some categories, based on impressionistic sociolinguistic descriptions of actual members of the English Department. We were surprised to discover that our categories were dichotomies (based on nationality, ethnicity and primary /home language). These dichotomies were: South African vs non-South African, African vs non-African, African-language speaker vs non-African language speaker. To this taxonomy we added gender (male vs female) and occupation (academic vs administrative; and academic $\&$ administrative vs support staff). This categorisation provided the basis for the prediction exercise. We were to make individual predictions on whether people from these different categories will want to learn Northern Sotho or not.

\section{Transforming Sociolinguistic Beliefs into Predictions}

To carry out the prediction exercise, we evolved a table to reflect the different categories. Given below (Table 2) is an example of this table as filled in by one member of the research team. The row headings represent the sociolinguistic categories mentioned above. The column headings show occupation (Academic, Administrative or Support) further classified into $\mathrm{M}$ (male) and $\mathrm{F}$ (female). Each of us used such a chart to privately write down ' $\mathrm{Y}$ '(Yes, this category would want to learn Northern Sotho) or ' $N$ '(No, this category would not want to learn Northern Sotho) in each cell.

To partially interpret the chart below, the team member who filled in this chart believes that academic male South African non-Africans (i.e. 'white' academic males, in this case) would not be motivated to learn Northern Sotho but white administrative males would be. Further, this member believes that females more than males ( 8 Ys for females vs 3 Ys for males) would be motivated to learn. 
Table 2 : An individual prediction chart

\begin{tabular}{|c|c|c|c|c|c|c|}
\hline & \multirow{2}{*}{$\begin{array}{r}\text { Academic } \\
\mathrm{M} \\
\end{array}$} & \multicolumn{2}{|c|}{ Admin } & \multicolumn{3}{|c|}{ Support } \\
\hline & & $\mathrm{F}$ & $\mathrm{M}$ & $\mathrm{F}$ & & $\mathrm{F}$ \\
\hline SA-NA & $\mathrm{N}$ & $Y$ & $\mathrm{Y}$ & Y & $N$ & $N$ \\
\hline SAA-NNS & $\mathrm{N}$ & $\mathrm{Y}$ & $N$ & Y & $\mathrm{N}$ & $\mathrm{N}$ \\
\hline SAA-NS* & -- & -- & - & -- & -- & -- \\
\hline NSA-A & $\mathrm{N}$ & $\mathrm{Y}$ & $\mathrm{N}$ & $\mathrm{Y}$ & -- & -. \\
\hline NSA-NA & $\mathrm{Y}$ & $\mathrm{Y}$ & $\mathrm{Y}$ & $\mathrm{Y}$ & -- & - \\
\hline
\end{tabular}

SA-NA:

SAA-NNS:

SAA-NS:

NSA-A :

NSA-NA :

\author{
South African Non-African \\ South African African Non-Northern Sotho \\ South African African Northern Sotho \\ Non-South African African \\ Non-South African Non-African
}

M: Male

F: Female

Y: Yes

$\mathrm{N}$ : No

*Note: This category is made up of first language speakers of Northern Sotho, so they would have no need to learn Northern Sotho. Hence there are blanks in this row.

In making these predictions, we each had to delve into an unarticulated set of assumptions about why an individual would want to learn an African language and what particular set of circumstances/conditions would motivate one to do so. Our predictions were therefore based on our implicit sociolinguistic beliefs. As one of us wrote (in an exploratory written reflection on the prediction exercise):

It came as a surprise to me to discover that I felt that non-South Africans would want to learn an African language as a way of integrating into the South African community, something that South Africans themselves may not need. I was also surprised to find that I believe that women more than men would want to learn a new language, hence unearthing a hunch that 1 know many people share.

All of us reported a growing sense of excitement about discovering the predictions of the other members of the team. To quote once again:

Having reflected on my own choices, I was eager to see how the other four members of the research team had reacted. Did they think the same categories that I had chosen would want to learn Northern Sotho? How close would the convergence be, how wide the divergence?

\section{Collective Prediction Analysis}

Once we had privately written down our individual predictions we decided to see what the collective picture looked like. We counted all the Ys ('yesses') and Ns ( 'nos') for each category of staff and thus collated a consolidated picture of our predictions. Among these we were struck by patterns of complete or near convergence and some divergence. In Table 3 below, we present only the $\mathrm{Y}$ (or yes) responses for ease of interpretation. The $\mathrm{N}$ (or no) predictions can be deduced. 
In Table 3 below, $5 \mathrm{Y}$ means that all five members of the research team predicted that that particular group of staff would want to learn Northern Sotho. For example, all five of us believed that both males and females in the SA-NA (South African Non-African i.e. 'whites') in the Administrative category would be motivated to learn Northern Sotho. The row totals of 30 stand for the maximum possible number of Ys for each row (i.e., if all 5 of us had predicted 'yes' for all 6 groupings in each category). The column totals of 20 represent the maximum possible number of Ys for each column (i.e., if all 5 of us had predicted 'yes' for all 4 categories who need to learn under each column heading).

Table 3: Collective positive predictions

\begin{tabular}{|l|l|l|l|l|l|l|l|l|l|}
\hline & 1 & 2 & 3 & 4 & 5 & 6 & 7 & 8 \\
\hline & Category & Acad & Acad & Admin & Admin & Supp & \multicolumn{2}{|c|}{ Supp } \\
\hline & & Motal \\
\hline A & SA-NA & $2 Y$ & F & M & F & M & F & \\
\hline B & SAA-NNS & $1 Y$ & $2 Y$ & $3 Y$ & $4 Y$ & $2 Y$ & $2 Y$ & $14 / 30$ \\
\hline C & SA-NS & -- & -- & -- & -- & -- & -- & \\
\hline D & NSA-A & $3 Y$ & $5 Y$ & $3 Y$ & $5 Y$ & -- & -- & $16 / 20$ \\
\hline E & NSA-NA & $5 Y$ & $5 Y$ & $4 Y$ & $5 Y$ & -- & -- & $19 / 20$ \\
\hline F & Total 'Y's & $11 / 20$ & $16 / 20$ & $15 / 20$ & $19 / 20$ & $4 / 10$ & $5 / 10$ & $70 / 100$ \\
\hline
\end{tabular}

$\begin{array}{lll}\text { SA-NA: } & \text { South African Non-African } & \text { M: Male } \\ \text { SAA-NNS: } & \text { South African African Non-Northern Sotho } & \text { F: Female } \\ \text { SAA-NS: } & \text { South African African Northern Sotho } & \\ \text { NSA-A : } & \text { Non-South African African } & \text { Y: Yes } \\ \text { NSA-NA : } & \text { Non-South African Non-African } & \text { N: No }\end{array}$

As can be seen, there are seven areas of total positive convergence ( 5 Ys in cells A4, A5, D3, $\mathrm{D} 5, \mathrm{E} 2, \mathrm{E} 3$ and E5). There are three areas of near positive convergence (4Ys in cells A3, B5 and $\mathrm{E} 4$ ). There is only one area of near negative convergence ( $1 \mathrm{Y}$ or $4 \mathrm{Ns}$ in cell B2).

If we look at the totals in row $\mathrm{F}$ and column 8 , we see that the $70 \%$ of our responses were positive: we therefore made a very high prediction that the UNIN population who did not know Northern Sotho would want to learn it. However, there was greater convergence for some categories than others. For example, the team predicted that female administrative staff and Non- South African Non Africans (NSA-NA) would be the most highly motivated to learn Northern Sotho. The group seen as least likely to want to learn Northern Sotho are South African African Non Northern Sotho (SAA-NNS) speakers (cell B2). This category would be made up of speakers of African languages spoken in South Africa other than Northern Sotho (i.e. Isizulu, Xitsonga, etc). 
The discussion on our collective predictions and our probing questions to each other on our individual beliefs were exciting. For example, we discovered that the African language speakers in the research team thought that the reason why SAA-NNS speakers would be least likely to want to learn Northern Sotho is because they already know it whereas the non Africans in the research team felt that since SAA-NNS speakers already know at least one African language, they would not want to learn another. These discussions created a positive affective climate in the team as we began to realise that beliefs cut across levels of education and professional status. i.e. people's beliefs are not determined by their status. It was interesting to note that despite the fact that we are from different backgrounds, we shared similar beliefs about many categories.

Other interesting observations can be made here but we reserve them for discussion in the section on matches and mismatches between our predictions and the data we collected from the English Studies Department.

\section{Data Collection Procedure}

Having completed the prediction exercise, we administered the questionnaire to staff of the English Studies Department (our pilot group) through a combination of private form filling and interview. The research assistants (HM, TM and SM) and the supervisors (MJ and ER) administered the questionnaires and therefore had a shared experience of the data collection.

Questionnaires were usually handed out to respondents and collected a few days later. When collecting the completed questionnaire, we sought more information through an interview. In the case of some respondents, the questionnaires were filled in the presence of the researcher and mediated through oral interaction. This was especially so with the one support staff member, a Northern Sotho speaker. In her case, the researcher verbally translated the questionnaire into Northern Sotho as she cannot read or write English (nor Northern Sotho).

\section{Data Collected on Section A of the Questionnaire}

Demographic and sociolinguistic data extracted from Section A of the questionnaire responses are presented in Table 4 . Nineteen of the 22 members of the English Studies Department returned completed questionnaires.

Table 4: English Studies Department: Demographic and sociolinguistic profile

\begin{tabular}{|c|c|c|c|c|c|c|c|c|c|c|}
\hline $\begin{array}{c}\text { Total } \\
\text { number } \\
\text { of staff }\end{array}$ & $\begin{array}{c}\text { Number } \\
\text { of } \\
\text { returns }\end{array}$ & $\begin{array}{c}\text { Number } \\
\text { of males }\end{array}$ & $\begin{array}{c}\text { Number } \\
\text { of } \\
\text { females }\end{array}$ & \multicolumn{4}{|c|}{ Age groups (in years) } & \multicolumn{3}{|c|}{ Nationality } \\
\hline & & & & $20-$ & $31-$ & $41-$ & $51-$ & $61-$ & SA & $\begin{array}{c}\text { Non- } \\
\text { SA }\end{array}$ \\
\hline 22 & 19 & 11 & 8 & 3 & 1 & 9 & 5 & 1 & 10 & 9 \\
\hline
\end{tabular}

\section{Nationalities of Non-South Africans}

Indian: 3; Dutch: 1; Swazi: 1; Congolese: 1; Ghanaian: 1; Zimbabwean: 1; British: 1.

\section{Languages spoken by the members of the English Studies Department}

Home languages:

English only: 3; Kiswahili: 1; English \& other: 3; Adangme: 1; Afrikaans: 3; Dutch: 1; Nothern Sotho: 3; Malayalam: 1; TshiVenda: 1; Shona: 1: Siswati: 1. 
Other languages:

English: 10; Hini: 3; Tamil: 1; French: 6; Afrikaans: 7; Zulu: 2; Xitsonga: 3;

German: 4; N.Sotho: 1; S.Sotho: 1; Chichewa: 1; Spanish: 1; Maori: 1; Ga: 1; Akan: 1;

Sanskrit: 1; Kannada: 1.

\section{Highest academic qualifications:}

Standard IV: 1; HED: 1; Diploma: 1; MA: 6; MPhil: 1; PhD: 9.

\section{Employment Status}

Permanent staff: $\quad 11$

Contract staff: $\quad 6$

Temporary staff: $\quad 2$

In analysing this data, we were struck by the linguistic diversity in the department. Among the 19 respondents, we have eight different nationalities, 7 of which are non-South African nationalities. Twenty-eight different languages are spoken within the department. This made us wonder about how many languages and nationalities we would get when we had completed our full survey of the University.

\section{Data Collected from Section B of the Questionnaire}

As mentioned earlier, our aim in Section B of the questionnaire was to establish how many staff members of the English Studies department already knew Northern Sotho. We also wanted to know how many had had previous experience of learning it and if they would be interested in joining Northern Sotho classes if a facility for this was provided.

In analysing the data, we classified the respondents in the following way. Those who do not know Northern Sotho were classified as having a 'need to learn', irrespective of whether they themselves perceived such a need or not. In other words, this was an 'objective' category. We decided that anyone who does not know Northern Sotho is a 'potential' learner. We say more about this category in the analysis of our data.

The next set of respondents was those who said they were interested in learning Northern Sotho. These we classified as those who 'want to learn'.

The third set of respondents were classified as 'actual' learners, because they had an objective need to learn the language, said that they want to learn it and actually attended lessons when they began. The figures for these categories are given in the table below.

Table 5: 'Need to learn', 'want to learn' and actual learners: data from English Studies

\begin{tabular}{|l|l|l|l|l|l|l|}
\hline & Total staff & $\begin{array}{l}\text { Total } \\
\text { returns }\end{array}$ & $\begin{array}{l}\text { Need to } \\
\text { learn } \\
\text { (potential } \\
\text { learners) }\end{array}$ & $\begin{array}{l}\text { Want to } \\
\text { learn }\end{array}$ & $\begin{array}{l}\text { Actual learners } \\
\text { (original list in } \\
\text { May 2000) }\end{array}$ & $\begin{array}{l}\text { Actual } \\
\text { learners } \\
\text { (Septem } \\
\text { ber } \\
\text { 2000) }\end{array}$ \\
\hline $\begin{array}{l}\text { Whole } \\
\text { dept }\end{array}$ & 22 & 19 & 15 & 13 & 7 & 3 \\
\hline
\end{tabular}


Before going on to analyze the data above, we would like to present the responses to the question (q 5) in Section B of the questionnaire on reasons for wanting to learn Northern Sotho. We present this data below.

\section{Table 6: Reasons given by English Studies staff for wanting to learn Northern Sotho}

\section{Reason}

\section{Number of respondents}

Better communication with people in the region: 5

A dominant majority language: 4

Aid to learning all three Sotho languages: 1

For survival: $\quad 1$

As an additional skill: 1

To understand what my students are saying and thinking: 1

For rapport with students:

To try out a new method: 1

To promote and develop African languages: 1

To understand the process of language learning: 1

To be accepted in the community where I live and work: 1

As can be seen, the main reasons have to do with communication in a dominant language of the region. As this was an open-ended question, several learners gave more than one reason.

A more detailed picture of the data in Table 5 is given in Table 7 below. It provides information on the four categories on which we made predictions with variables such as gender, nationality, occupation and primary language/s (or linguistic background). It also gives more refined information on the categories that 'need to learn', 'want to learn' and are actually learning Northern Sotho. 
Table 7: The results of the data analysis: responses according to sociolinguistic and demographic categories from the English Studies department

\begin{tabular}{|c|c|c|c|c|c|c|c|}
\hline & $\begin{array}{l}\text { Total } \\
\text { (Dept) }\end{array}$ & $\begin{array}{l}\text { Total } \\
\text { returns }\end{array}$ & $\begin{array}{l}\text { Know } \\
\text { Northern } \\
\text { Sotho }\end{array}$ & $\begin{array}{l}\text { Need: } \\
\text { Potential } \\
\text { Learners }\end{array}$ & Want & $\begin{array}{l}\text { Actua } \\
\text { Learn } \\
\text { May } \\
2000\end{array}$ & $\begin{array}{l}\text { ers } \\
\text { Sept } \\
2000\end{array}$ \\
\hline & 22 & 19 & 4 & 15 & 13 & 7 & 3 \\
\hline Male & 13 & 10 & 2 & 8 & 6 & 2 & 1 \\
\hline Female & 9 & 9 & 2 & 7 & 7 & 5 & 2 \\
\hline SA & 14 & 11 & 4 & 7 & 7 & 2 & - \\
\hline Non-SA & 8 & 8 & 0 & 8 & 6 & 5 & 3 \\
\hline Academic & 20 & 17 & 2 & 15 & 13 & 7 & 3 \\
\hline Admin & 1 & 1 & 1 & 0 & - & - & - \\
\hline Support & 1 & 1 & 1 & 0 & $-^{*}$ & - & - \\
\hline SA-NA & 7 & 6 & 0 & 6 & 6 & 2 & - \\
\hline SAA-NNS & 2 & 1 & 1 & $-* *$ & - & - & - \\
\hline SA-NS & 4 & 3 & - & - & - & - & - \\
\hline NSA-A & 4 & 4 & 0 & 4 & 2 & 1 & 1 \\
\hline NSA-NA & 5 & 5 & 0 & 5 & 5 & 4 & 2 \\
\hline
\end{tabular}

\section{Notes}

* This respondent (the only support staff member in English Studies, who is a first-language speaker of Northern Sotho) expressed a need to learn to read and write in Northern Sotho.

** This respondent, who is a first-language speaker of Venda, has picked up Northern Sotho informally, can read it but would like to be able to write it.

As can be seen from Table 7, out of the 19 staff members who returned questionnaires, 15 do not know Northern Sotho and were therefore classified as those who 'need' to learn Northern Sotho. According to our definition of 'additive multilingualism', full membership of a community involves having at least a basic knowledge of the majority language/s of the province. In other words, as mentioned earlier, we are defining 'need' as an objective category which stands for 'absence' of such knowledge. All 15 respondents who do not know Northern Sotho are therefore 'potential learners' of Northern Sotho. 
Out of the 15 who 'need' Northern Sotho, 13 'want' to learn it. 'Want' here represents a subjective perception by the respondent indicating motivation and willingness to learn. However, we need a word of caution here. Our research team suspected that some respondents might have given the 'politically correct' answer by indicating a 'Yes', i.e. 'Want to learn'. This suspicion may be supported by the fact that only 7 of the 13 who 'want' to learn actually joined the Northern Sotho Language project (NSLP) classes, when the lessons began in May 2000. At the time of writing (September 2000) only 3 out of these 7 are still continuing to attend lessons. This low figure (only 3 out of 15 , i.e. $1 / 5$ th of those who 'need' Northern Sotho) may be partly due to logistical reasons and work pressures, and therefore calls for further investigation.

\section{Matches and Mismatches between our Predictions and the Data}

We examine here the matches and mismatches between our predictions and this data, according to variables such as gender, nationality, occupation and linguistic background. This analysis involves a comparison of the collective positive predictions we made (Table 3) and the data we collected (Table 7).

\section{Predictions Based on Gender}

Though chronologically gender was a category we identified after nationality, ethnicity and occupation, it turned out to be the one that we subjectively found most interesting, and the one that evoked the most heated discussions.

Out of the 8 male staff in the English department who need to learn Northern Sotho, 6 indicated that they want to learn but only 2 became actual learners in the project. However, all 7 female staff said they want to learn and 5 of them became actual learners. When working out the percentages, we had to match the potential learners against the actual learners. In the gender category we got $71 \%$ for females ( 5 out of 7 ) and only $25 \%$ for males ( 2 out of 8 ). Our interpretation of these percentages is that our prediction that females would be more motivated to learn Northern Sotho was confirmed by the data.

\section{Predictions Based on Occupation}

If we analyse the collective positive predictions (Table 3 ) we can see that we predicted that administrative staff would be more motivated than academic staff. We had 34 Ys for administrative staff (both male and female) out of a possible 40 Ys as compared to 27 Ys for academic staff. In our discussion it emerged that this prediction is informed by our feeling that administrative staff probably interact more with students than academics do and for a wider variety if reasons (to organise finance, accommodation, library facilities, etc ). It is also likely that academic staff interact with students in English, not Northern Sotho, another hypothesis that awaits empirical research.

But our prediction about administrative staff could not be tested because there was no data from the English Studies department. The only administrative staff member (the departmental secretary), is a native speaker of Northern Sotho and is also literate in the language. She therefore has no need to learn it. This category was therefore deemed unconfirmable in the pilot study. This has motivated us to seek more data from other departments so that we can test our prediction about administrative staff.

the highest divergence among the research team is on the prediction for support staff. We had only 9 positive predictions out of a possible 20 positive predictions (for both male and female staff). In other words, there were 11 negative predictions out of 20 . It turned out that this 
divergence had to do with our differences about the linguistic background of support staff. Some of us think that they are a homogenous linguistic group (mainly Northern Sotho, which would mean that they do not need to learn it) and others who see support staff as being more heterogeneous (including many non-Northern Sothos).

The only support staff member (a cleaner) in the English Studies department is Northern Sotho, speaks it fluently but has a need for literacy in the language.

\section{Predictions Based on Linguistic Background}

We had predicted that there would be few South African African-Non Northern Sotho speakers wanting to learn Northern Sotho. As mentioned earlier, this is partially informed by the feeling of South African members of the research team (DM, TM and SM) that South African-Africans are already multilingual in several African languages and therefore will not need to learn Northern Sotho. This category was also untestable because there is only one South African-African Non Northern Sotho speaker in the department, who is already extremely fluent in Northern Sotho. Whether this is true of other African language speakers at UNIN awaits the collection of more data.

\section{Predictions Based on Nationality}

Under nationality, we had the subcategories Non-South Africans-Non Africans (NSA-NA), and South African-Non Africans (SA-NA). We predicted that NSA-NAs would be more willing and motivated to learn Northern Sotho than SA-NAs. Here the data also confirmed our predictions because we obtained $60 \%$ for NSA-NA ( 3 out of 5 ) and only $33.3 \%$ for SANA ( 2 out of 6 ). Incidentally, in the Northern Sotho Language Project, there are more Non South Africans (17) than South African-Non Africans (5) learning Northern Sotho.

Though more SA-NAs claimed they 'wanted' to learn Northern Sotho, (6 out of 6 or $100 \%$, as shown in Table 7) thus refuting the prediction of the group, more NSA-NAs actually attend classes. $60 \%$ (or 3 out of 5) of potential NSA-NA learners enrolled for lessons. This is a high percentage of the NSA-NA population in the dept, as compared with only $33.3 \%$ of the SA-NAs who enrolled. In other words, $2 / 3 \mathrm{rds}$ of the NSA-NAs are actual learners compared to only $1 / 3$ rd of SA-NAs. Therefore our prediction that more NSA-NA staff would 'want' to learn is entirely confirmed.

Interestingly two of the NSA-A staff who said they did not 'want' to learn are actually learning Northern Sotho, one informally through conversations with first-language speakers and the other through private instruction. Two NSA-NAs reported attempts at learning another African language than Northern Sotho. Among the SA-NAs, one learner reported learning Northern Sotho through informal conversation. The data on methods of learning Northern Sotho for the two groups (NSA-NAs and SA-NAs) have not yet been fully analysed. However such data would prove to be interesting in the context of the project's claim that naturalistic ways of learning a second/other language are effective, whether these approaches emanate from within or outside classrooms.

Overall summary of Matches and Mismatches between Our Predictions and Data from the English Studies Department

A consolidated picture of the matches and mismatches is presented in Table 8. 
Table 8: Predictions and data: matches \& mismatches

\begin{tabular}{|l|l|l|l|}
\hline & Prediction & Data & Interpretation \\
\hline Gender & $\begin{array}{l}\text { Females more } \\
\text { motivated than males }\end{array}$ & $\begin{array}{l}71 \% \text { of females } \\
25 \% \text { of males }\end{array}$ & Confirmed \\
\hline Occupation & $\begin{array}{l}\text { Administrative staff } \\
\text { more motivated } \\
\text { than academic staff }\end{array}$ & $\begin{array}{l}\text { No data from English } \\
\text { Studies }\end{array}$ & Unconfirmable \\
\hline $\begin{array}{l}\text { Linguistic } \\
\text { background }\end{array}$ & $\begin{array}{l}\text { SAA-NNSs less } \\
\text { motivated than other } \\
\text { categories }\end{array}$ & $\begin{array}{l}\text { No data from English } \\
\text { Studies }\end{array}$ & Unconfirmable \\
\hline Nationality & $\begin{array}{l}\text { NSA-NAs more } \\
\text { motivated } \\
\text { than SA-Nas }\end{array}$ & $\begin{array}{l}60 \% \text { of NSA-SAs } \\
33.3 \% \text { of SA-NAs }\end{array}$ & Confirmed \\
\hline
\end{tabular}

As mentioned earlier, where our predictions are unconfirmable, we are motivated to search for such data in other departments at UNIN.

\section{CONCLUSION}

What we discovered from our experience is that when researchers make predictions about social groups in a socially-familiar environment and articulate their hunches to each other an exciting journey of self discovery begins. We initially undertook the prediction exercise to make large-scale quantitative research more interesting for us, but on the way we discovered several cognitive and social uses for prediction. These are presented in the rest of this article.

\section{Cognitive uses of Prediction}

\section{(a) Search for more data:}

Our predictions led to a preoccupation with 'whose prediction is right?' Predictions that did not match the data collected were not readily accepted as outright disproof but led to a strong desire to collect more data that might possibly reverse the finding. In cases where the team was divided, the two differing groups experienced a feeling of sporting competitiveness to get more data. This inner compulsion is very different from the usual sense of duty and impatience to 'complete the survey'.

Researchers whose prediction was proved 'right' experienced a sense of satisfaction, but also sought to look for more data that might constitute disproof. The whole exercise of matching predictions with data became more like a challenging game than an affirmation of diverse dogmatic beliefs.

\section{(b) Search for new kinds of data}

Often we did not find the categories of staff within the English department for whom we made predictions. For instance, there were no administrative staff members in need of learning Northern Sotho within the department as there was only one female 
administrative staff and she is a Northern Sotho speaker. Getting data on female administrative staff who need to learn Northern Sotho was important as the entire research group converged in predicting that this would be the group who would most want to learn Northern Sotho.

Other 'missing' categories from the English department were African-language speaking but non-Northern Sotho male staff who needed to learn Northern Sotho. A third 'missing' category was non-Northern Sotho support staff. Another category that we overlooked was students of UNIN. No predictions were made about this category as we assumed they would not want to learn Northern Sotho and our study was restricted to staff. But when the classes began, to our surprise, two students joined. Both were non-Northern Sotho African-language speaking students. We learnt that more students want to join classes.

The frustration of not finding these categories within our department has led us to search for such groups in other departments. For example we realised there are some departments 'rich' in female administrative non-Northern Sotho speakers, and we are determined to target these departments.

\section{Interpretation/theorising on an Ongoing Basis:}

The matching of predictions with data collected led to immediate theorising about groups and their language needs. The differences within the research team were a further resource for theorising. This led to an ability to 'hold' data and theory in our heads while moving forward to collect more data. There was much 'Why?' and 'I wonder if...' talk among the research team. This ongoing, piece-meal theory construction is different from the usual practice of the massive collection of data, and the 'final sitting down' to see what it all adds up to, a process we nearly embarked on ourselves at the beginning but abandoned as soon as we felt we were getting lost in the data.

\section{Social Uses of Prediction}

(a) Recovery of assumptions/beliefs:

The predictions we made were initially forward looking towards the data, but often led to mutual questioning as to why individuals made those predictions. We realised that behind our predictions were very definite beliefs. Articulating these beliefs for each other made these beliefs available to the whole group and enabled us to see how predictions are grounded in beliefs. The recovery of these beliefs aroused a sense of curiosity and respect for 'where people are coming from'.

\section{(b) Solidarity and affective climate of research team}

Our predictions led to an unanticipated feeling of group excitement and solidarity. When we reflected on why this was the case we came out with the following explanation: predictions are both easy to generate but also put people at ease. This is because it is not knowledge-based but belief-based. In a group where there are supervisors and students, hierarchy comes in the form of the possession of superior knowledge, which is usually academic knowledge. Beliefs, however, are something everyone possesses. Moreover, beliefs are not subject to the judgement of being 'right' or 'wrong', 'better' or 'inferior'. One experiences equality at the level of beliefs. One also experiences curiosity at differences. One gets to value beliefs as a 
resource for hypotheses and precuictions, and a group sees everyone as possessing this resource.

Learning about each other's beliefs thus came to be seen as a vital part of community research, in the dual sense of a group (or community) doing research, but doing it in a way that makes the group into a 'community' rather than just a task force. There is of course a danger of a group getting too inward-looking. We therefore need to balance the tension between the forward-looking role of predictions to get more and new kinds of data (i.e., be product driven) and the inward-looking role of examining beliefs.

\section{CONCLUDING THOUGHTS ON RESEARCH METHODOLOGY}

Returning to the issue of research methodology, we support the call for large-scale quantitative data made by both LANGTAG and GLR. However, we disagree with GLR's claim that the view that knowledge is 'constructed' is now accepted by all professionals today and that there might be only the odd 'Rip van Winkelish natural scientist' who rigidly sticks to a purely positivistic view (Muller 1999:62).

Our experience in universities shows that novice researchers are inducted into a very positivistic view of knowledge, further reinforced by their earlier undergraduate education, where they are trained to be scholarly at the expense of their own point of view. The struggle to get students to find and value their own voice is as much an issue for postgraduate students doing research as it is for their undergraduate counterparts.

But staff are no exception. Our subjectivities rooted in our hidden beliefs are often censored by notions of 'objectivity' and academic respectability. This is further reinforced by the pressure to conform to a stylistically-voiceless academic discourse that all academics are trained to master. While we agree with GLR that positivism has been denounced and constructivism acknowledged at a philosophical plane, research practices are a different matter. This is why we believe subjectivity has to be reclaimed at the level of research practice and ways of using it need to be explored and extended.

\section{ACKNOWLEDGEMENTS}

We would like to thank the Editor and an anonymous reviewer for valuable feedback. ENDNOTE

\footnotetext{
'An earlier form of this article was presented as a paper at the Southern African Applied Linguistics Association annual conference in September 2000.
}

\section{REFERENCES}

GRANVILLE, S, H JANKS, M MPHAHLELE, Y REED, P WATSON M JOSEPH \& E RAMANI. 1998. English with or without $g(u)$ ilt: a position paper on Language in Education policy in South Africa. Language and Education 12(4):254-272 
JOSEPH, M AND E RAMANI, E. 1997. Making monolinguals multilingual. AD Issues 5(1):15-17.

JOSEPH M AND E RAMANI E. 1998. The ELT specialist and linguistic hegemony. ELT Journal, 52(3):214-22.

[LANGTAG]. 1996 Towards a National Language Plan for South Africa Final report of the Language Plan Task Group presented to the Minister of Arts, Culture, Science and Technology, 8 August 1996.

MULLER J. 1999. Reason, reality and public trust: The case of educational research for policy. In Taylor, $\mathrm{N}$ and $\mathrm{P}$ Vinjevold (eds), Getting learning right. Report of the President's Education Research Project. Johannesburg: The Joint Education Trust:3764.

PRABHU, NS. 1987. Second Language Pedagogy Oxford: Oxford University Press.

TAYLOR, N AND P VINJEVOLD (eds). 1999 Getting learning right. Report of the President's Education Research Project. Johannesburg: The Joint Education Trust.

VINJEVOLD, P AND N TAYLOR. 1999. Research methods. In Taylor, N and P Vinjevold (eds), Getting learning right. Report of the President's Education Research Project. Johannesburg: The Joint Education Trust:65-104.

\section{Bibliographic Note}

The authors are five of the members of the Northern Sotho Language Project (NSLP) at the University of the North (UNIN). 


\section{Appendix A}

\section{Questionnaire}

Please fill both sections of this questionnaire. Place an $X$ in the relevant box, where needed. Thank you.

\section{Section A.}

1. Name (Withhold your name if you wish)

2. Gender: Male $\square \quad$ Female $\square$

3. Age (please circle your age group): $20-30 \quad 30-40 \quad 40-50 \quad 50-60 \quad 60-70$

4. Nationality: SA $\square$ Non-SA $\square$

5. Specify your country

6. Home /First language/s

Other language/s

7. Highest academic qualification.

8. Faculty

9. Department

10. Category of staff: Academic $\square$ Administrative $\square$ Support $\square$ Permanent $\square$ Temporary $\square$ Contract $\square$

\section{Section B}

1. How would you rate your competence in Northern Sotho? Sotho on the scale provided below?

A. None $\square \quad$ Beginner $\square \quad$ Intermediate $\square \quad$ Advanced

B. None $\square$ Understand $\square \quad$ Speak $\square \quad$ Read $\square \quad$ Write $\square$

2. Have you tried to learn N. Sotho before?

Yes $\square \quad$ No 
3. If the answer is 'yes', what methods of teaching were used?

Grammar teaching $\square$ Conversation classes $\square$ Use of translation

Other $\square \quad$ Specify.

4. If Northern Sotho lessons were held on campus would you like to learn it? Yes $\square \quad$ No

5. If your answer is 'yes', give reasons why you would like to learn Northern Sotho?

6. What level of competence would you like to achieve?

Understand $\square \quad$ Speak $\square$

Read $\quad \square \quad$ Write

7. How many hours per week would you wish to attend Northern Sotho classes? 


\section{Appendix B}

\section{The Northern Sotho Language project, UNIN}

Methodology: Problem-solving, task-based teaching and learning within a naturalistic, psycholinguistic paradigm

Teacher-researchers: Two postgraduate students in English Studies: Maite Mmako \& Mafori Makgahlela

Research assistants: Hlulani Mabasa (postgraduate student in Adult Education), Thembinkosi Mabila and Simon Mothoa (postgraduate students in English Studies)

Learners: $15-20$ academic and administrative staff at UNIN and two students

Lessons: Two one-hour lessons weekly since May 2000. Material for 30 lessons and homework tasks on real-life themes produced so far.

Training: Materials are trialled in weekly training sessions on the two supervisors, who are also learners on the project.

Community Research: Classroom-centred research (videodata), learner studies, diary studies, multilingual survey of UNIN

Outputs: Module for Northern Sotho department, video training manual, learner materials, translation of literature, songs and other cultural material into Northern Sotho, research publications 